\title{
INTEGRUOTOS PAGALBOS MODELIO PAIEŠKOS EPILEPSIJA SERGANTIEMS IR RAIDOS SUTRIKIMŲ TURINTIEMS VAIKAMS BEI JUOS AUGINANČIOMS ŠEIMOMS
}

\author{
Polina Šedienè $\dot{1}^{1}$ Ramunẻ Jurkuvienè ${ }^{1}$, Rūta Butkevičienė ${ }^{1}$, Lina Danusevičienè1, \\ Indrè Gajdosikiené2 \\ ${ }^{1}$ Lietuvos sveikatos mokslu universiteto Visuomenès sveikatos fakulteto Bioetikos katedra, \\ ${ }^{2}$ Vilniaus universiteto Filosofijos fakulteto Sociologijos ir socialinio darbo institutas
}

Raktažodžiai: vaikų epilepsija ir raidos sutrikimai, šeimos poreikiai, ị vaiką ir šeimą orientuota pagalba, integruota pagalba.

\section{Santrauka}

Epilepsija - lètinis, įvairių priežasčių nulemtas neurologinio pobūdžio sutrikimas. Trečdalis epilepsija sergančių vaikų turi raidos sutrikimų. Tokios būklès vaikams reikalinga ilgalaikè priežiūra, kurią užtikrina tèvai. Paprastai daugiausia dèmesio skiriama epilepsijos medicininiams aspektams, tačiau tyrimai rodo, kad stigmatizacija bei negatyvios ligos ịveikimo strategijos, naudojamos vaikų ir jų artimujų, kartais sukelia vaiko gyvenimui dar sunkesnių padarinių, nei pati liga, todèl situacija tampa sunkiai pakeliama našta tèvams. Siekiant pagerinti tokių šeimų gyvenimo kokybę, naujausiuose tyrimuose daug demesio skiriama paciento ir jo šeimos poreikių analizei. Lietuvoje atliktas kokybinis tyrimas, skirtas išsiaiškinti poreikius, reikalingus pagalbos modeliui konstruoti. Apklausta 12 mamų, auginančių epilepsija sergančius sutrikusios raidos vaikus. Tyrimas atskleide, kad tevams svarbus su vaiko sveikatos būkle ir priepuolių stabilizavimu susijusių poreikių tenkinimas, tačiau ne mažiau svarbūs vaiko ugdymo ir socializacijos poreikiai bei psichoemocinè ir socialinè parama. Tèvai dažnai jaučiasi vieni su savo problemomis, nepaisant ịvairių sistemų jiems teikiamų paslaugų. Būdinga, kad sergantys vaikai ir šeimos, užuot integravęsi ị visuomenę, atsiriboja nuo jos. Jei pagalba bei paslaugos šeimoms, auginančioms epilepsija sergančius sutrikusios raidos vaikus, būtų teikiamos remiantis ị vaiko ir šeimos poreikius orientuotu modeliu, susiejančiu sveikatos, ugdymo ir socialines sistemas (integruojant jas tiek horizontaliai, tiek vertikaliai), šių šeimų ir vaikų (jaunuolių) situacija pagerètų.
Kaip vienas pagrindinių integruotos pagalbos modelio elementų straipsnyje pristatomas specializuotas epilepsijos psichosocialinio konsultavimo centras.

\section{Ivadas}

Epilepsija - viena dažniausių neurologinių lètinių ligų, tačiau manoma, kad jai skiriama nepakankamai demesio. PSO iniciatyva, gydytojų ir mokslininkų tyrejų Tarptautinè lyga prieš epilepsiją bei pacientams ir jų artimiesiems atstovaujantis Tarptautinis epilepsijos biuras pradejo pasaulinę kampaniją prieš sergančiųų epilepsija socialinę stigmatizaciją, reikalaudami epilepsiją traktuoti kaip rimtą lètinę neurologinę ligą, reikalingą specifinio gydymo ir paslaugų [1]. Pasaulio sveikatos asamblejos rezoliucijoje WHA68.20 akcentuojama integruoto veikimo dèl epilepsijos naštos svarba, kai šalies lygmeniu sujungiami sveikatos, socialinio ir viešojo sektoriaus ištekliai, siekiant pagerinti sergančiujų epilepsija ir jų artimujų gyvenimo kokybę, plètojant paslaugas ir jų prieinamumą [2]. Kaip atsakas ị šị PSO kvietimą plečiamas tyrimų apie sergančiųų epilepsija ir jų šeimos narių poreikius bei gyvenimo kokybę spektras, kuriami ir išbandomi integruotos pagalbos modeliai.

Epilepsijos paplitimas priklauso nuo daugelio veiksnių ir šalies geopolitinès bei socioekonominès situacijos [3]. Tyrimai rodo, kad vaikams epilepsija pasireiškia daug dažniau, nei kitose amžiaus grupèse. Ypač pažeidžiami vaikai pirmaisiais gyvenimo metais, o 10 metų amžiaus grupejje epilepsijos dažnis susilygina su suaugusiųų amžiaus grupe [4]. Jungtinès Karalystès (JK) tyrèjai atskleidžia, kad vaikų ir jaunuolių iki 25 metų epilepsija yra vienas dažniausių lètinių ilgalaikès priežiūros reikalingų neurologinių sutrikimų. Epilepsijos paplitimas Lietuvoje atitinka jos paplitimo kitose Europos šalyse lygị: JK epilepsija pasireiškia vidutiniškai 1 iš 200 vaikų ir jaunuolių iki 25 metų. Lietuvoje 2019 m. to paties amžiaus grupés vaikų ir jaunuolių epilepsijos ir epilep- 
sijos būklès skaičius buvo 1 iš 170 . Nuo epilepsijos kenčia $15 \mathrm{mln}$. vaikų pasaulyje. Tai susirgimas, pasireiškiantis ne vien priepuoliais, bet ir sutrikusiu elgesiu, socialine, fizine ir proto negalia. Epilepsija apibūdinama kaip nevienalytė kompleksinè situacija [5]. Trečdaliui aktyvia epilepsija sergančių vaikų būdingi intelekto ir raidos sutrikimai [6]. Esant sunkiai intelekto ir raidos negaliai, pusė sergančiųų gali patirti epilepsijos priepuolius. Dvigubai daugiau sergančiujų epilepsija ir proto negalia kenčia nuo psichikos sveikatos sutrikimų, nei turintys vien tik proto negalią. Kaip ypatingi psichikos sveikatos sutrikimo rizikos veiksniai nurodomi kai kurie traukulių požymiai: stiprumas, dažnumas ir kt. [7]. Paminètinas ir vaistų nuo epilepsijos šalutinis poveikis, galintis pasireikšti ne tik biologiniame, bet ir psichosocialiniame lygmenyje. Tyrimais nustatyta, kad šalutinis vaistų poveikis dažnesnis ir intensyvesnis tų epilepsija sergančių jaunesniojo amžiaus vaikų elgesiui, kuriems būdingas ankstyvasis hiperaktyvumas (impulsyvumas) [8].

Epilepsijos priepuoliai gali ịvykti bet kuriuo paros metu ivvairiose buvimo vietose: darželyje, mokykloje, pramogu centre, todèl dažnai sergantieji, vengdami nemalonių klausimų, patyčių ar pažeminimo, apsiriboja bendravimu savo šeimoje. Tyrimų duomenys ir praktika rodo, kad sergantieji epilepsija bei jų artimieji dažnai naudoja negatyvias ligos ịveikos strategijas $[9,10]$ ir dèl bejejgiškumo bei informacijos stokos nepasinaudoja socialinès, teisinès ir kitos pagalbos galimybėmis. Atlikti pasauliniai tyrimai [11] parodè, kad sergančiųjų epilepsija gyvenimo kokybė gerejja, gerẻjant jiems skirtų paslaugų kokybei. Prieš tai tyrejjai, diskutuodami su paslaugų organizatoriais, turèjo pripažinti, jog medikų ir kitu pagalbos teikèjų bendravimas su sergančiaisiais - skurdus, todèl turètų būti keičiamas. Tyrimas parodè, kad yra ir kitu išteklių bei ịvairių kitos pagalbos sergantiems epilepsija galimybių, kurios iki šiol nèra tinkamai išnaudojamos [7].

Lietuvoje epilepsija sergančių vaikų ir jų šeimų gyvenimo kokybę, netgi gerai vaistais gydomo susirgimo atveju, gali sunkinti nepagrịstai didelis vaikų saugojimas institucijose, perdèti draudimai. Dèl negatyvių išgyvenimų šeimos, kuriose auga epilepsija sergantis sutrikusios raidos vaikas (toliau - EpR vaikas), dažniau patiria socialinių problemų. Dažnai dèl ligos ir aplinkos reagavimo ị ją susiformuoja pernelyg globejjiškas tėvų auklèjimo stilius, kuris veda vaikus į nesavarankiškumą, sąmoningumo ir socialinių kompetencijų stoką [11]. Galimi epilepsija sergančių vaikų ir jų šeimos narių psichosomatiniai ir prisitaikymo sutrikimai, todèl svarbu teikti pagalbą, atsižvelgiant ị EpR vaikų bei jų šeimų poreikius.

Tyrimo tikslas - atskleisti EpR vaikų bei jų šeimu poreikius, pagalbos galimybes bei pateikti pagal tyrimo duomenis sukonstruotą integruotos pagalbos modeli.

\section{Tyrimo medžiaga ir metodai}

Tyrimo strategija. Siekiant parengti pagalbos šeimoms, auginančioms EpR vaikus, modeli, formuluojami tyrimo klausimai: 1. Kokie yra šeimų, auginančių EpR vaikus, poreikiai? 2. Kokio pobūdžio pagalba ir paslaugos atlieptų šeimų, auginančių EpR vaikus, poreikius? Tyrime atlikti kokybiniai giluminiai pusiau struktūruoti interviu su EpR vaikus auginančiais tèvais. Tokio pobūdžio interviu leidžia tyrejjams nukreipti pokalbị i tam tikras juos dominančias temas, teikia galimybę informantams laisvai atskleisti savo gyvenimo realybę (patirti, požiūrius) [12] ir šios realybès pagrindu konstruoti pagalbos vaikui ir šeimai modelį. Ieškant atsakymo ị ivardytus tyrimo klausimus, numatyti vedamieji pusiau struktūruoto interviu klausimai: 1 . Su kokiais vaiko priežiūros ir šeimos funkcionavimo sunkumais susiduria EpR vaikus auginančios šeimos? 2. Kokio pobūdžio pagalbą (paslaugas) gauna šios šeimos? 3. Kokio pobūdžio pagalbos (paslaugų) šioms šeimoms trūksta?

Tiriamujų atranka. Siekiant atskleisti kuo platesnị tiriamų šeimų patirčių diapazoną, taikyta tikslinė atranka [12]. Pagrindinis atrankos kriterijus - šeimos, auginančios EpR vaikus. Kiti atrankos kriterijai buvo vaiko amžius, sirgimo epilepsija trukmé, epilepsijos priepuolių intensyvumas, vaiko raidos sutrikimo pobūdis. Informantai rasti padedant istaigoms (organizacijoms) ir jų specialistams, dirbantiems su EpR vaikais ir juos auginančiomis šeimomis, tèvus vienijančiuose socialiniuose tinkluose, Epilepsijos psichosocialinio konsultavimo centro Facebook puslapyje, tiesiogiai susisiekiant su šeimomis.

Tyrimo dalyviai. Tyrimo analizès vienetas - šeimos, auginančios EpR vaikus. Šių šeimų atstovès buvo mamos. Apklausta 12 mamų, auginančių EpR vaikus, iš kurių 10 dirbančios. Dvi mamos vaikus augino vienos, kitos - kartu su vaikų tèvais. EpR vaikų amžius svyravo nuo 4 iki 17 metų: 3 ikimokyklinio amžiaus (4-5 metų), 2 - mokyklinio (11-12 metų) ir 7 paaugliai (12-17 metų). Lytis -5 berniukai ir 7 mergaitès. Šešiems EpR vaikams epilepsija diagnozuota kūdikystejje. Epilepsijos priepuolių raiškos diapazonas svyravo nuo „šiuo metu priepuoliai sustabdyti“ iki labai stipriu ir dažnu priepuoliu pasikartojimo. Raidos sutrikimai svyravo nuo lengvų (mokymosi sutrikimai) iki sunkių (negalinčių judèti ir kalbèti).

Tyrimo eiga. Interviu vyko informantès pasirinktoje jai patogioje vietoje. Trukmè - nuo $45 \mathrm{~min}$. iki 2 valandų. Transkribuoti interviu garso ịrašai buvo analizuojami taikant indukcinę ir dedukcinę kokybinę turinio analizę [12,13]. Pradiniame etape kiekviena tyrëja individualiai sukodavo savo atliktus interviu. Vèliau bendros kategorijos ir temos buvo išskirtos visų tyrejjų diskusijų pagrindu. Siekiant rezultatų patikimumo ir validumo, taikyta tyrimo metodų triangu- 
liacija: interviu turinio analizè, tyrèjų diskusinès grupès, duomenų analizès rezultatų tikslinimas [13].

Tyrimo etika. Visos informantès, supažindintos su tyrimo idejja ir tikslais, savanoriškai sutiko dalyvauti tyrime. Informančių konfidencialumas užtikrintas neatskleidžiant duomenų, leidžiančiu identifikuoti tiriamuosius. Cituojant, informančių vardai pakeisti.

Tyrimo rezultatai pateikiami ir interpretuojami atsižvelgiant $i$ tyrimo klausimus ir atsiskleidusias temas. Pirmoje dalyje pateikiami tyrimo metu atsiskleidę EpR vaikus auginančių šeimų poreikiai bei jų analizè. Antroje dalyje analizuojant pagalbą bei paslaugas EpR vaikus auginančioms šeimoms, aptariamas integruotos pagalbos bei bendrujų ir specialiujų paslaugų plètros poreikis. Pabaigoje siūlomas pagal tyrimo duomenis sukonstruotas integruotos pagalbos modelis.

\section{Tyrimo rezultatai ir jų interpretacija}

Šeimų, auginančių EpR vaikus, poreikiai. Visoms vaikus auginančioms šeimoms būdingi bendrieji poreikiai, priklausantys nuo vaiko amžiaus ir šeimos raidos tarpsnių. Vaiko liga, raidos sutrikimas ar negalia sukelia papildomu iššūkių šeimai, lyginant su tomis, kuriose vaikų raida normali [14]. Vaiko kompleksinio sveikatos sutrikimo atveju, apimančiu epilepsiją ir ịvairius raidos sutrikimus, išryškēja specifiniai vaiko ir šeimos poreikiai. Šioje straipsnio dalyje pateikiami ir aptariami EpR vaikus auginančių šeimų poreikiai, susiję su 1) vaiko sveikatos būkle ir priepuolių stabilizavimu, 2) vaiko ugdymu ir socializacija bei 3) psichoemociniai ir socialiniai šeimos, auginančios EpR vaiką, poreikiai.

Su EpR vaiko sveikatos būkle ir priepuoliu stabilizavimu susije poreikiai. Epilepsijos ir raidos sutrikimų nulemti poreikiai, susiję su vaiko sveikatos būkle, apima maksimalaus priepuolių retinimo, jų intensyvumo mažinimo, komplikacijų išvengimo poreikị; reabilitacijos, slaugos ir palaikomojo gydymo, reikalingo raidos sutrikimų, ypač cerebrinio paralyžiaus atvejais, poreikị ir kitus. Išryškèjo nuolatinès medicininès stebėsenos poreikis, kai stebima, ar neblogejja paciento būklè, ar nesivysto komplikacijos. „Atliekami nuolat tyrimai. Nors nebèra priepuolių, elgsena [dukros] gali būti susijusi su epilepsija. Jos tas trankymas, daužymas ì stalą" (Olga).

Svarbus yra saugumo poreikis, nes priepuolio metu galima traumų, užspringimo, susižeidimo, nuskendimo ir pan. rizika. Ji susijusi su profesionalios informacijos poreikiu, kaip įveikti priepuolio baimę, atpažinti jo artėjimą ir apsaugoti vaiką, priepuoliui ištikus. Šis poreikis apima suvokimą apie ligą ir pagalbos priepuolio metu galimybių ivertinimą. Suvokimui formuotis reikia informacijos: „kas ta per epilepsija? Kokia jos forma [dukrai] pasireiškia? Mes matę, kai [vaikai] krenta ant žemès traukuliuose, o [dukra] ne. Jai tik židiniai galvoje yra, kurie buvo tik specialistams matomi..." (Oresta).

Kai epilepsija sergantis vaikas turi ir raidos sutrikimų, atsiskleidžia nuolatinès kokybiškos nemedikamentinès terapijos ir slaugos poreikis. ,[Lenkijoje] yra toks reabilitacijos centras. Tai ten visas kompleksas reabilitacijų: valandą laiko dirba su vaiko rankomis, per rankas lavina. Valandą - akių terapija, tai ten su sensorika [dirba], fizioterapija dvi su puse valandos $<\ldots>$. Per tas 2 savaites vaikas sustiprèja žymiai. Čia pas mus ateini, tai valstybè skiria pusę valandos. İ tą 30 min. įeina apsirengimas, vaiką reikia paruošti, tu turi nurengti, jis pasportuoja ir turi aprengti, nes jau po tavęs laukia kitas" (Irena). Išvardytų poreikių spektro platumas ir patenkinimo galimybių ivairovè glaudžiai siejasi su epilepsijos intensyvumu bei raidos sutrikimų sudetingumu. Kuo sunkesnè epilepsijos eiga ir kuo sudètingesnè negalia, tuo daugiau specifinių poreikių turi šeima, tuo sudètingiau juos patenkinti.

EpR vaiko ugdymo ir socializacijos poreikiai. Mamos, dalyvavusios tyrime, išreiške „,buvimo su savo bendraamžiais" svarbą vaiko gyvenime. Vieni tèvai akcentavo vaikų bendravimą su bendraamžiais, turinčiais panašių sutrikimų, nes tokioje aplinkoje vaikas jaučiasi saugiau. Tèvai tikisi, kad vaikas ,socializuosis, turès daugiau žmonių, iš kurių ko nors išmoks" (Klara). Kitos šeimos siekia vaiko normalumo: „iprastas vaikas, ịprastoj mokykloj, su ịprastais santykiais“ (Laima). Tačiau vaiko poreikis bendrauti ir būti su bendraamžiais dèl ịvairių priežasčių yra sunkiai patenkinamas. Esant kompleksiniams vaiko poreikiams, net ir specialioji ugdymo įstaiga ne visada užtikrina jo socializacijos ir ugdymo galimybes. Viena priežasčių - nèra mokytojo padèjëjo. „Mokykla neskiria padèjèjo tai klasei. [EpR sūnus] ramus vaikas, bet jis tarsi stabdis. $<>$ Jo negali palikti vieno. Auklètoja viena, vaikų daug... Ji nebuvo patenkinta, kad jai užkrauna [EpR vaiką]“ (Ina).

Sudètinga EpR vaiko ugdymo ir socializacijos situacija susiklosto jam mokantis bendrojo ugdymo įstaigose. Tèvai deda daug pastangų, kad vaikas neatsiliktų ugdymo procese: ,...sèdim po dvi, tris valandas - ir verkimų būna, visko čia būna, bet reikia, kad būtų tie pažymiai, geresni rezultatai“ (Laima), nors tyrimai rodo, kad labai svarbu užtikrinti optimalų EpR vaiko krūvị, atitinkantị jo gebejjimus [15]. Dèl mokykloje patiriamų patyčių (,...tu debilè, tu nieko nemoki, tu tokia, tu anokia"), EpR vaikai šalinasi bendraamžiu, „vengia sveikų vaikų ir bijo bendrauti“ (Veronika). Šeimai siūloma keisti mokymo įstaigą, nors tai ypač sudètinga sutrikusios raidos vaikams. Priimant epilepsija sergančius vaikus ì mokyklą, dažnai keliama sąlyga, kad nebūtų priepuolių, 
pervertinamos priežiūros problemos [16]. „Pasakè, kad [EpR vaikas] negeba adaptuotis ir liepé mokyklą keisti. Tris mokyklas pakeitėm. $<\ldots>$ Po to ir prasidèjo tie savęs žalojimai, kalbos apie savižudybę“" (Veronika).

EpR vaikus auginančios šeimos patiria ir vaikų tèvų priešiškumą. Tik retais atvejais sutinkamas kompetentingas pedagogas, gebantis suvaldyti situaciją ir rasti būdu palengvinti vaiko adaptaciją bei socializaciją: ,...turèjome situaciją, kai vienas tėvas surinko parašus, kad sūnų iškeltų, nes jis pavojingas grupès vaikams. Visa laimé, kad auklètoja teisingai sureagavo [pasakè tam tèvui, kad] ,jūsų mergaitei bus lengviau persiorientuoti kitoje grupejje, negu jam; jei nepatinka, eikite ị kitą grupę“ (Birutè).

Tyrimas atskleide, kad tuomet, kai mokyklos bendruomené, vaiko draugai nesupranta situacijos, o tèvai nepajègūs advokatauti, ne tik neprasideda neigalaus vaiko integracija, bet kyla jo socializacijos pavojus. Svarbu, kad šị klausimą specialistai aptartų su tévais ir pasiūlytų pagalbą tėvams ir vaikui, jeigu to reikètų. Kitu atveju dažnai šeima, noredama apsaugoti vaiką nuo galimų neigiamų aplinkinių reakcijų, nes ,pas draugus jisai bijo, kad nepaklaustų, nuo ko vaistai, ką tu čia geri ir aiškintis ten" (Laima), apsiriboja ryšiais tik su pačiais artimiausiais šeimos nariais.

Kartais tèvai iš baimès, kad ateityje nebūtų apkaltinti, sąmoningai kliudo vaiko draugystems ir nutraukia besiformuojančius meilès ryšius, atriboja paaugli nuo darbo santykių. Tẻvų hipergloba užkerta kelią jo socializacijai, savarankiškumui ir gebejjimui socialiai įsitvirtinti. Toks tèvų auklëjimo stilius kelia grèsmę net ir ịvardytos negalios neturintiems vaikams užaugti socialiai neigaliais [5]. Mamos pastebejjo, kad yra svarbu išlaikyti pusiausvyrą tarp hiperglobos ir „pabėgimo“.

Psichoemociniai ir socialiniai šeimos, auginančios EpR vaika, poreikiai. Motinos pabrèžè informacijos ir palaikymo poreikį. „Kai gimsta toks vaikas (kitoks), tai instruktažo niekas nepaduoda: kaip nori, taip susigaudyk... Reikia padèti tai šeimai surasti pagalbą... Aišku, yra socialiniai darbuotojai, kurie teikia tas informacijas, bet ar jie viską žino? Dukra kai gimè, tai aš tik po metų sužinojau, kad mums iš tikruju priklauso sauskelnès nemokamai, bet mes už viską mokèjom. Kol nesusidūriau su kitom mamom, kurios pasakè..." (Jūratè). Tinkamai pagalbai būtų svarbu pirmiausia tèvams padèti susigyventi su šokiruojančia vaiko diagnoze, išklausyti jų baimes ir palaikyti pertvarkant savo gyvenimą, padedant suprasti, kokio pobūdžio epilepsija vaikui, atskirti, kur priepuolis, o kur sutrikęs elgesys, koks yra šalutinis vaistų poveikis, ir pan. Vaiko priežiūros eigoje tèvai išmoksta šios informacijos ieškoti ir ja pasinaudoti, tačiau pradžios etapui (sužinojus diagnozę) būdingas tèvų sutrikimas ir pasimetimas, todèl informacijos apie pagalbos galimybes ir perspektyvas teikimas tėvams, bei būdas, kaip ji suteikiama, tuo metu yra labai svarbus. Šio pobūdžio informacija padètų šeimoms sužinoti, kokios pagalbos reikètų vaikui („Nežinau, kokių paslaugų reikia prie epilepsijos, kur kokios įstaigos ir specialistai veikia, kokią pagalbą suteikia, kokia parama priklauso šeimai ir ar apskritai kas nors priklauso“ (Klara). Informacija apie pagalbos galimybes tèvams taip pat padetų šeimoms, nes „kai tu rūpiniesi vaiku, tu net neturi laiko ieškoti dèl savęs" (Ina). Informacijos poreikis yra vienas iš dažniausių šeimose, auginančiose ịvairių sveikatos sutrikimų turinčius vaikus. Šis poreikis siejamas su visuotiniu tèvu poreikiu jausti, kad jie gali kontroliuoti situaciją [17]. Dažnai jis lieka nepatenkintas ir dèl kitų priežasčių, arba tėvai nemoka ar nedrịsta paklausti gydytojo juos neraminančių klausimu. , ,...Neurologe skyre dar papildomą vaistą $<\ldots>$, bet kai pakalbejjau su žmonėmis, kurie tą vaistą vartoja visame pasaulyje, tai supratau, kad bus beda“"(Regina). Suprantamai pateikta neurologo informacija, medikų dialogas su tèvais sustiprintų pasitikejimą profesionalais bei taikomu gydymu.

Tyrimo metu išryškèjo psichoemocinio šeimos palaikymo poreikis, pradedant šeimos gedejjimu dèl vaiko netekties, ligos, priepuolių baimès, nuolatinès įtampos, aplinkinių požiūrio. Mamos pasakojo, kad „Mama ar anyta iš pradžių buvo piktos, kodèl taip atsitiko, nu kaip dabar gimè neigalus vaikas...“ (Klara), „Vyro šeima yra atsiribojusi, nelabai supranta“" (Ina). Jeigu artimieji negauna atitinkamos informacijos ir emocinès pagalbos, jiems sunku priimti pati vaiką ir pokyčius, kurių reikalauja vaiko situacija, ar ịsitraukti ị pagalbos vaikui procesą. Situacijos paaiškinimas aplinkiniams yra atskira šeimų, auginančių neiggalius vaikus, poreikių grupé, apimanti ir šeimos narius, ir kitą šeimos socialinę aplinką [18]. Šeimos ir vaiko poreikiai labai susiję. Tẻvai dažnai gyvena vaikų gyvenimus, jaučia vidinę psichoemocinę priklausomybę nuo sergančio vaiko. Tyrimas atskleidè, jog darbas tèvams yra ne tik pragyvenimo šaltinis, bet ir tam tikra galimybe atsitraukti nuo neiggalaus vaiko priežiūros, socializacija ir savirealizacija. Tyrimas atskleidè vaiko priežiūros poreikị, kai tèvai būna darbe, o taip pat ir kitais atvejais: „Mūsų santykiai pašlijo... Daug darėme dèl vaiko, bet mažai kartu... Kai išgirdome apie atokvépio galimybę, projektas jau buvo pasibaigęs" (Ina). Svarbu atkreipti dèmesį, kad atokvèpio poreikis tèvams būtų derinamas su vaiko ugdymo, jo komunikavimo gebejjimų formavimo ir socializacijos poreikiu.

Integruota pagalba bei paslaugos EpR vaikams ir jų šeimoms. Nagrinejjant tyrimo antrojo klausimo duomenis, t.y. kokio pobūdžio pagalba ir paslaugos atlieptų EpR vaikų ir jų šeimų poreikius, paaiškejjo, kad tyrimo rezultatams atskleisti reikalingi skirtingi analizès pjūviai. Vienas pjūvis apima paslaugų integralumo būtinybę horizontalaus ir vertikalaus integralumo prasme: horizontalus integralumas siekia įveikti 
siauro žinybiškumo sukeliamas paslaugų teikimo problemas; vertikalaus integralumo siekinys - išvengti paslaugų teikimo fragmentiškumo ir išlaikyti nuoseklumą bei tęstinumą, atsižvelgiant ị ligos pobūdį, paslaugų poreikị, amžiaus tarpsnius, laikantis etinių paslaugų teikimo principų. Kitas analizès pjūvis atskleidžia, kad pagalba EpR vaikus auginančioms šeimoms turètų apimti bendrąsias paslaugas, aktualias visoms šeimoms, ir specialiąsias, kurios atlieptų specialiuosius EpR vaikų ir jų šeimų poreikius, atsižvelgiant ị epilepsijos intensyvumą ar raidos sutrikimų sunkumą. Šios paslaugos atitinka LR socialinių paslaugų ịstatymo 8 straipsnyje pateikiamą apibūdinimą, bet tyrimas parodè, kad ši samprata turi būti plečiama. Trečiasis pjūvis apima pagalbos organizavimo lygmenis (mikro-, mezo- ir makro-).

Analizuojant horizontalų paslaugų integruotumą (ivairių paslaugų suderinimą, atsižvelgiant ị šeimų poreikius), svarbu suvokti, kad šiuo metu paslaugos Lietuvoje planuojamos ir teikiamos dažniausiai laikantis (vertikalaus) žinybiškumo principo: kiekvienas paslaugų teikẻjas atlieka savo funkcijas, o ne tyrinejja šeimos poreikius ir, bendradarbiaudamas su kitų sričių specialistais, integruoja pagalbą EpR vaikams ir jų šeimoms: atskirai teikiamos medicininès, socialinès ir švietimo paslaugos. Ilgus metus dominavo medikalizuotas pagalbos modelis, kai visas dèmesys buvo sutelktas ị epilepsijos gydymą vaistais ar chirurgine intervencija, nors medikamentiné pagalba sudaro tik vieną devintają visos EpR vaikui ir jo šeimai reikalingos pagalbos [11]. Vertikalaus integruotumo užtikrinimo pavyzdžiu sveikatos sistemoje gali būti dalinimasis informacija ir gydymo derinimas tarp šeimos gydytojo ir neurologo-epileptologo (skirtingų sveikatos sistemos lygių).

Ilgas demokratijos tradicijas turinčiose šalyse, pvz., Vokietijoje, teikiama kompleksinè integruota pagalba apima ne vien medikamentinę, bet ir psichosocialinę pagalbą. Šioje šalyje yra aštuoni epilepsijos centrai (pvz., www.bethel.de; www.kleinwachau.de), kurių klinikose dirba daugiadalykès komandos, aprépiančios ir paciento šeimos, socialinių ryšių, užimtumo problematiką. Klinikose planuojama ilgalaikẻ ligonio socialinė priežiūra, ambulatorinès globos ir paslaugu namuose galimybès, vyksta tikslingos psichosocialinès konsultacijos, pacientų ir jų šeimos narių mokymai, suteikiama galimybė vaikui igyti specialybę.

Integruotos pagalbos, i paciento poreikius orientuotas modelis reikalauja kitokio profesionalų požiūrio, paslaugų teikimo ir jų organizavimo, kai paslaugos teikiamos individualizuotai. Pagalba teikiama pirmiausia bendradarbiaujant su tevais, pradedant nuo neformalios pagalbos stiprinti šeimu pastangas, igalinti šeimas padeti vienas kitoms ir baigiant specifine profesionalų pagalba, kai gydytojai, slaugytojai, kinezi- ir ergoterapeutai, logopedai, specialieji pedagogai, psichologai ir socialiniai darbuotojai specializuojasi epilepsijos srityje, teikdami paslaugas vaikams ir jų šeimoms.

Tyrimo duomenys atskleide, kad EpR vaikus auginančioms šeimoms, kaip ir daugumai šeimų Lietuvoje bei kitose buvusiose totalitarinèse (sovietinèse) šalyse, trūksta suvokimo, kas yra socialine paslauga, kaip ji konstruojama, kiek išteklių reikalauja paslaugos kūrimas ir teikimas, kaip jos finansuojamos. Atsakomybė rūpintis EpR vaiku paliekama vien šeimai arba perkeliama valstybei (pvz. EpR vaiko apgyvendinimas globos namuose). Trūksta suvokimo, kad valstybè padeda taip, kad neužgožtų asmens ar jo šeimos iniciatyvos, bet ir nepaliktų su nepakeliama našta. Vis dar plačiai paplitęs visvaldès, neišsemiamus išteklius turinčios valstybės įvaizdis, pagal kurị mistinè valstybè, su kuria, jų supratimu, eiliniai žmonès turi mažai ką bendro, privalo teikti visiems (bent jau sunkios būklès asmenims) tobulai organizuotas, aukščiausios kokybès ir nemokamas paslaugas. Situacija komplikuojasi, kai vietoje kognityvinio, argumentais pagrįsto pasitikejjimo valstybès teikiamomis paslaugomis, dažnai sutinkamas emocinis (ne)pasitikejjimas, kuris argumentais nesiremia [19]. Šeimos naudojasi paslaugomis, bet neanalizuoja, koks yra paslaugų teikimo mechanizmas ir kas moka už paslaugas, iš kokių fondų kompensuojamos slaugos priemonès ar vaistai. Gal tuo galima paaiškinti tyrimo metu atsiskleidusị tẻvų nepasitenkinimą ir kritiką paslaugų teikèjams, akcentuojant frazę: „esu viena ir niekas man nepadeda“. Šeimos paprastai nesigilina ir neivvertina, kiek daug jos jau gauna paramos ir paslaugų, už kurias nemoka. Dažniausiai tèvai naudoja frazę: „priklauso“ nemokamos paslaugos ir prekès arba „nepriklauso“. Jiems vis dar sunku suvokti, kad nemokamų paslaugų nebūna, tik už jų dali moka savivaldybė (valstybè), t.y. visi mokesčių mokètojai, laikydamiesi solidarumo principo, todèl labai svarbu didinti šeimų sąmoningumą, suvokiant jų poreikius informacijai. „Yra Facebook'as visagalis, kuriame labai daug informacijos. Tik svarbu atsirinkti. Yra labai daug tèvų grupių“ (Jūratè). Specialistų konsultacijos šeimai rūpimais klausimais - svarbi paslauga ir specialistų funkcija. Kita vertus, jei paslaugos tarpusavyje nekoordinuojamos, i tėvų balsą mažai įsiklausoma, tèvams lengva pasijusti, kad jų ir jų vaikų gyvenimas bei patiriami sunkumai niekam iš tikrujjų nerūpi. Duomenys, gauti tyrimo metu, patvirtino literatūroje pateiktus teiginius, kad teikiant viešojo sektoriaus paslaugas, sisteminiu lygmeniu nèra sukurta praktikos, kai organizacijose taikomi subsidiarumo ir šeimos savireguliacijos pripažinimo principai, grižtamojo ryšio teikimas, pagarbus požiūris ị klientą, integralumo laikymasis, kai paslaugos atliepia visuomenès poreikius [19].

Ypač svarbu individualizuotai išsiaiškinti šeimos, auginančios vaiką su negalia, poreikius, kuriuos iš jų šeima 
gali pati užsitikrinti ir kokios pagalbos šeimai reikia iš kitų: artimiausios aplinkos žmonių ir specialistų. Svarbu, kad pagalbos gavejjai ir teikejjai gerbtų ir vertintų vieni kitų pastangas padèti vaikui, vengtų nuoskaudų liejimo, priekaištu ir galios demonstravimo. Analizuojant gautus duomenis išryškejja, kad tiek mokesčių moketojų išteklius skirstantys valdininkai, tiek socialinių paslaugų gavejjai sunkiai suvokia dialogo tarp šeimos ir specialistų profesionalų būtinybę, paslaugų pagal poreikius teikimo mechanizmus ir stokoja strategijų, kaip juos kurti. „Svarbu, kad specialistai bendradarbiautų su tèvais, nes niekas taip nepažista savo vaiko kaip mama. Ji parodo, kas vaikui patinka, kas nepatinka; kaip su tuo vaiku elgtis. Nes ką tu ten perskaitai literatūroje, tai tik teorija..." (Daiva).

Paslaugos, atliepiančios EpR vaiko poreikius, turètų būti skirstomos ị bazinių paslaugų paketą ${ }^{1}$ ir papildomas paslaugas, kurių ịvairovė, kaip atskleidžia poreikių analizè, yra labai plati. Bazinis paslaugų paketas turètų būti fokusuotas ị EpR vaiko sveikatos būklès stabilizavimą ir vaiko savarankiškumo, priklausomai nuo raidos sutrikimo, ugdymą ir palaikymą. Esminis klausimas, kas ir kurias paslaugas (sveikatos, psichosocialinès pagalbos ir švietimo) įtraukiant turètų sudaryti bazinị paslaugų paketą. Vadovaujantis subsidiarumo principu, kuriuo turètų būti grindžiamas paslaugų teikimas, pirmiausia turi būti igalinama pati šeima, jos artimiausia aplinka, o tik po to dèmesys turètų būti skiriamas tai pagalbai, kurios šeima nepajègi savo pastangomis susiorganizuoti, palaikant jų pačių iniciatyvą.

Akivaizdu, kad šalia neformalios pagalbos svarbu profesionalų teikiamos paslaugos. Pagrindiniai šių paslaugų teikimo EpR vaikams ir jų šeimoms siekiniai turètų būti nukreipti i epilepsijos stabilizavimą ir savarankiškumo ugdymą.

Organizuojant paslaugas EpR vaikams ir šeimai, svarbu pastebèti, kad gyvenimas nuolat kinta ir paslaugu teikimas negali būti statiškas, rigidiškas. Augant vaikui, keičiasi paslaugų poreikis ir šio poreikio atliepimo galimybès. „Problema yra auklès... Kol dar buvo mažas, buvo lengviau. O dabar [vaikui 15 metų] su žiburiu nerasi, kas su juo pabūtų <..>. Aš jo negaliu palikti, nè viena įstaiga jo nenori, nes yra per didelè rizika..." (Birutè). Tiesiogiai su vaiku bendraujantis personalas nurodè, kad dèl EpR vaikų sveikatos būklès ypatumų (bet koks pokytis kelia stresą ir gali lemti vaiko elgesio pokyčius ar epilepsijos priepuolius), išryškèjo paslaugų rutiniškumo ir pastovumo poreikis.

${ }^{1}$ LR Vyriausybès $2019 \mathrm{~m}$. birželio $19 \mathrm{~d}$. nutarimu Nr. 618 ,Dèl bazini paslaugų šeimai paketo patvirtinimo“" patvirtintas Bazinis paslaugų šeimai paketas, pritaikytas socialinius sunkumus patiriančioms šeimoms, bet neatliepiantis epilepsija sergančių sutrikusios raidos vaikų ir jų šeimų bazinių poreikių. Šiame straipsnyje analizuojama, kokios bazinès paslaugos būtinos epilepsija sergantiems sutrikusios raidos vaikams ir jų šeimoms.
Tyrimo metu atsiskleide didelis atokvėpio paslaugų ir dienos centru poreikis. Tyrimas atskleidè, kad atokvėpio paslaugos, teikiamos pagal savivaldybès nustatytą tvarką, dažnai yra nelanksčios, vaikai su negalia sunkiai priima pasikeitusią vietą ir žmones. „Dažnai pagalbos iš žmonių sulauki žymiai daugiau, negu iš valstybès. Su ta valstybe sunku susitarti: kol ịrodème, kad atokvèpio reikia“ (Odeta). Svarbu, kad pagalbos teikejjai stiprintų šeimų pastangas ir padètu joms tik tada, kai pačios šeimos nepajègia sau padèti. Savitarpio pagalba gali būti gerokai lankstesnè ir trukme, ir vieta, ir santykiu. Tokia pagalba šeima-šeimai labai skatintina. „Prieš kelias savaites aš gavau dovanų i Birštoną, $\dot{i}$ spa. Mums abiems su vyru. Tai draugè išleido. Ji turi keturis vaikus. Viena iš jų neiggali mergyte, sunki kompleksinè negalia kaip manosios. „Atvežk, - sako, - man savo chebrą. Pažiūrèsiu.“ Taip 7 vaikai buvo ir du iš jų neịgalūs (su sunkia negalia)" (Irena). Atkreiptinas demesys, kad profesionalu organizuojama savigalba jokiu būdu nèra visos atsakomybès perdavimas šeimoms. Tai kūrybos ir ịsiklausymo reikalaujantis darbas, kai teikiant profesionalią pagalbą, šeimų ịgalinimas yra vienas svarbiausių veiksnių, gerinančių specialistų teikiamų paslaugų kokybę.

Integruotos pagalbos modelio konstravimas. Specializuotas epilepsijos psichosocialinio konsultavimo centras. Pagal poreikius organizuojant ir teikiant pagalbą EpR vaikams ir jų šeimoms, svarbu derinti ir integruoti medicinines, ugdymo ir psichosocialines paslaugas ambulatorinemis ir stacionarinėmis sąlygomis. Dienos socialinès globos, struktūruoto mokymo ir terapinio ugdymo paslaugos turètų būti teikiamos ambulatorinèmis sąlygomis, derinant pagalbą namuose su pagalba institucijose. Išryškejjus poreikiui integruoti paslaugas, siūlytina ịkurti specializuotą epilepsijos psichosocialinio konsultavimo centrą, teikianti paslaugas EpR vaikams ir jų šeimoms. Šiame centre vaikai galètų gauti integruotą pagalbą: juos konsultuotų neurologas epileptologas, dirbtų epileptologè slaugytoja, veiktų reabilitacijos komanda. Vaikai būtų mokomi ir ugdomi pagal specialias programas, individualiai konsultuojami, gautų dienos centro, veikiančio darželio principu, paslaugas.

Pagal indikacijas būtu prieinama ir stacionarinè pagalba: teikiamos medicininès reabilitacijos, vaikų raidos sutrikimų ankstyvosios reabilitacijos paslaugos, atokvèpio paslaugos tẻvams. Vaikams, turintiems specifinių kalbos ir kalbejjimo, judesių, psichologinių, socialinès raidos sutrikimų, elgesio, psichikos ir emocijų sutrikimų, lengvą, vidutinį, sunkų, gilų ar kitą nepatikslintą protinį atsilikimą, profesionalią pagalbą teiktų atitinkami profesionalai.

Socialinè pagalba, reikalinga vaikams ir jų šeimoms, turètų apimti: tinklo kūrimą su gydytojais (pediatrais neurologais-epileptologais, slaugytojomis epileptologėmis, 
reabilitacijos komandos specialistais, besispecializuojančiais teikti pagalbą vaikams, sergantiems epilepsija ir turintiems raidos sutrikimu, ir kt.), klinikomis ir reabilitacijos įstaigomis, biurais, valdžios institucijomis ir kitomis panašiomis tarnybomis bei nuoseklų bendradarbiavimą šiame tinkle; įvairių šalių (EpR vaiko, tėvų, profesionalų ir kitų su vaiku susijusių asmenų) informavimą bendraisiais epilepsijos (ligos paveikslas, diagnozé, gydymas, skubioji pagalba, parama ivveikiant ligą), finansiniais ir teisiniais (pašalpos, neigalumo pripažinimas) klausimais; apie namų aplinkos formavimą, kad būtų išvengta susižeidimų per priepuolius, apie ypatingus pavojus ir riziką (pvz., skendimas, informacija apie tinkamas pagalbos priemones); siuntimą arba palydèjimą ị kompetentingas tarnybas ir institucijas; patarimų teikimą, kaip elgtis po pirmojo epilepsijos priepuolio; konsultavimą socialiniais klausimais, integravimo ị vaikų darželi ar mokyklą iššūkių aptarimą; pagalbą îveikiant kasdienes gyvenimo situacijas (pvz., mobilumas, laisvalaikio planavimas, šeimos atokvépio galimybès), kolegialų atvejų konsultavimą ir tęstinį mokymą bendradarbiaujant su vaikų darželiais ir mokyklomis, neịgaliụu įstaigomis; pasiūlymus dèl palaikymo gyvenant su liga, pvz., mokymus ir susitikimus sergantiems asmenims ir jų artimiesiems, savitarpio pagalbos grupių kūrimą. Cen- tras ị pagalbą teikti paslaugas galètų pasitelkti ir savanorius, taip prisidedamas prie platesnio visuomenès įsitraukimo ir informavimo apie epilepsiją. Šie darbai ir paslaugos sudaryti pagal EpR vaikų ir jų šeimų tyrimo metu išsakytus poreikius.

EpR vaikų šeimoms padetų internetiniai forumai, paslaugų žemèlapis: įstaigos, projektai, specialistai, parama. Informacija turètų disponuoti ir ją teikti specialistai organizacijose (savivaldybèje). Tẻvams ir EpR jaunuoliams būtų vertinga galimybe konsultuotis specializuotais su epilepsija susijusiais klausimais ir gauti palaikymą telefonu (epilepsijos „karštoji linija“).

Integruotos pagalbos modelis EpR vaikams ir šeimoms (pagal tyrimo duomenis). Vakarų šalyse intensyviai kuriami integruotos pagalbos modeliai, leidžiantys sujungti išteklius, išvengti paslaugų fragmentiškumo ir užtikrinti pagalbos pacientui tęstinumą. Jungtinès Karalystès mokslininkai, išstudijavę pagalbos epilepsija sergantiems vaikams (jaunuoliams) kliūtis, sukūrè integralios pagalbos modelį, kuris leistų įveikti komunikacijos trikdžius tarp specialistų ir vaiko bei šeimos, sustiprintų komunikaciją sistemoje, padètų spręsti epilepsijos diagnostikos, profesinès specializacijos epilepsijos srityje problemas, leistų išvengti paslaugų fragmentiškumo. Autorių nuomone, gyvybiškai būtina speci-

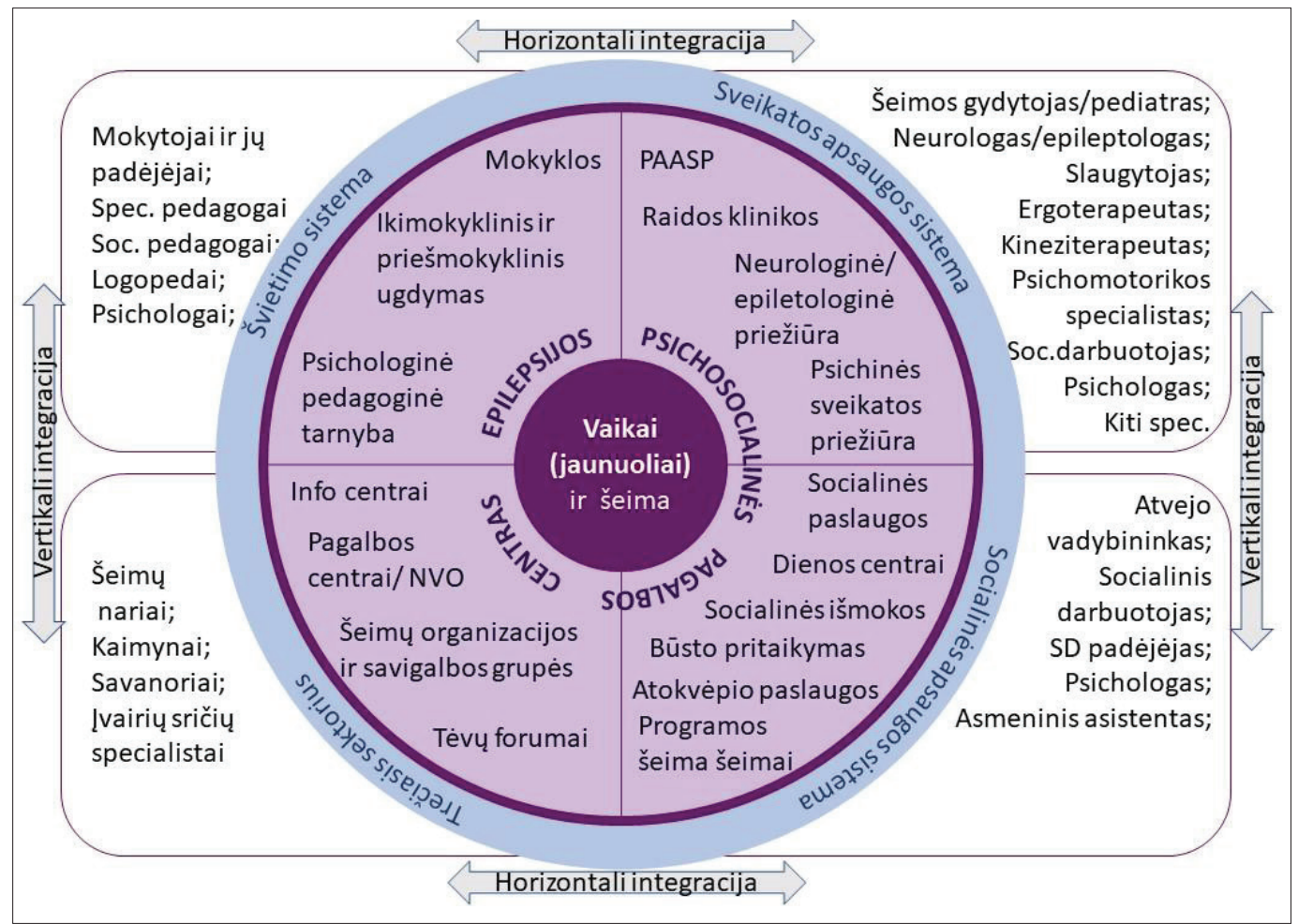

1 pav. Integruotos pagalbos modelis EpR vaikams ir šeimai

Šaltinis: parengtas autoriu pagal šio tyrimo duomenis 
alistams pereiti prie dialogu ir partneryste grịstų santykių su vaikais (jaunuoliais) ir jų tèvais [20]. Net sékmingais atvejais, kai medikamentiniu gydymu pavyksta visiškai apsaugoti nuo ligos priepuolių ir valdyti ligos eigą, epilepsija sergantys jaunuoliai patiria mokymosi sunkumų, elgesio ir emocijų sutrikimų [20]. Šiems vaikams būtina integruota ìvairių institucijų ir sistemų (sveikatos priežiūros, socialinès pagalbos ir švietimo) pagalba. JK modelio raktinis elementas - nacionalinis epilepsijos registras, leidžiantis ne tik matyti individualų pagalbos planą, bet ir fiksuoti būklès pokyčius, o priklausomai nuo jų koreguoti pagalbą ir sistemų įtrauktį, individualios pagalbos plano pakeitimus. Šio modelio kūrèjai isitikinę, kad pagalbos sistemos dinamiškumas ir galimybe kaupti ịvairiapusę informaciją leistų giliau pažinti epilepsijos formų įvairovę, bei kaip ši liga paveikia vaikų ir jaunuolių gyvenimus.

Remiantis mūsų tyrimo duomenų ir kitų šalių pagalbos modeliu analize, sukonstruotas integruotos pagalbos teikimo modelis EpR vaikams (jaunuoliams) ir šeimai (1 pav.). Šio modelio taikymas puikiai atspindi integruotos pagalbos galimybes anksčiau aptartame specializuotame epilepsijos psichosocialinio konsultavimo centre, koncentruotame ị individualizuotą pagalbą EpR vaikui ir jo šeimai.

Pagalbos veiksmingumas priklauso ne tik nuo to, kaip integraliai veikia kiekviena sistema, sprendžianti vaiko ir šeimos iššūkius, išryškejus epilepsijos ir raidos sutrikimams, bet ir kaip skirtingų sistemų sektoriai veikia kartu, nuo pagalbos tarp skirtingų sektorių koordinavimo. Pagalbos EpR vaikui (jaunuoliui) modelis grịstas ị asmens poreikius orientuota pagalba, kuri tarsi apglèbia vaiką (jaunuolį) ir jo šeimą pagal įvairias poreikių sferas. Nors epilepsijos priepuolių kontrolè ar jų išnykimas yra svarbi gydymo dalis, bet integruotos pagalbos modelio kontekste tai yra tik viena sudedamoji siektino rezultato dalis [20]. Apie gydymo sèkmę sprendžiama analizuojant ir kitus EpR vaiko gyvenimo rodiklius, pavyzdžiui, kaip pagerejo pažangumas, mokyklos lankomumas, kaip dabartinis vaiko gyvenimas padeda ruoštis suaugusiojo gyvenimui, ugdo jo savarankiškumą, kaip didina galimybes dalyvauti darbo rinkoje.

Vertindami, ar individualus pagalbos planas atitinka i asmens poreikius orientuotą pagalbos modelį, analizuojame, ar teikiama pagalba suteikia šeimai (artimiesiems, ịstatyminiams vaiko globejjams) erdvès didesnei EpR vaiko situacijos kontrolei.

\section{Išvados}

1. Šeimos, auginančios epilepsija sergančius ir raidos sutrikimų turinčius vaikus, nurode ne tik su vaiko sveikatos būkle ir priepuolių stabilizavimu susijusius, bet ir vaiko ugdymo, socializacijos, psichoemocinius bei socialinius poreikius. Nepaisant vaikui teikiamų įvairių paslaugų šeimos dažnai jautėsi vienos, vietoje integracijos patirdamos izoliaciją.

2. Analizuojant pagalbą bei paslaugas šeimoms, auginančioms epilepsija sergančius sutrikusios raidos vaikus, turi būti laikomasi ị šeimos ir vaiko (jaunuolio) poreikius orientuoto pagalbos principo, pagalba turi būti vertikaliai ir horizontaliai integruota.

3. Vienas pagrindiniu integruotos pagalbos modelio šeimoms, auginančioms epilepsija sergančius sutrikusios raidos vaikus, elementuc yra specializuotas epilepsijos psichosocialinio konsultavimo centras.

\section{Literatūra}

1. Reynolds EH. The ILAE/IBE/WHO global campaign against epilepsy: bringing epilepsy "out of the shadows". Epilepsy Behavior 2000;1(4):S3-S8.

https://doi.org/10.1006/ebeh.2000.0104

2. World Health Organization. Global burden of epilepsy and the need for coordinated action at the country level to address its health, social and public knowledge implications. Resolution WHA68 2015;20:26.

3. Beghi E. The epidemiology of epilepsy. Neuroepidemiology 2020;54(2):185-191. https://doi.org/10.1159/000503831

4. Camfield P, Camfield C. Incidence, prevalence and aetiology of seizures and epilepsy in children. Epileptic Disorders 2015;17(2):117-123.

https://doi.org/10.1684/epd.2015.0736

5. Geerlings RPJ, et al. Failed transition to independence in young adults with epilepsy: the role of loneliness. Seizure 2019;69:207-212.

https://doi.org/10.1016/j.seizure.2018.07.003

6. Olusanya BO, Wright SM, Nair MKC, et al. Global burden of childhood epilepsy, intellectual disability, and sensory impairments. Pediatrics 2020;146(1):e20192623.

https://doi.org/10.1542/peds.2019-2623

7. Sander JW. Comment: improving the care of people with epilepsy and intellectual disabilities. Neurology 2015;85(17):15191519 .

https://doi.org/10.1212/WNL.0000000000002074

8. Guilfoyle SM et al. Antiepileptic drug behavioral side effects and baseline hyperactivity in children and adolescents with new onset epilepsy. Epilepsia 2018;59(1):146-154. https://doi.org/10.1111/epi.13946

9. Räty LK, Wilde-Larsson BM. Patients' perceptions of living with epilepsy: a phenomenographic study. J Clin Nurs 2011;20(13)-14:1993-2002.

https://doi.org/10.1111/j.1365-2702.2010.03572.x

10. Deegbe DA, Aziato L, Attiogbe A. Experience of epilepsy: coping strategies and health outcomes among Ghanaians living 
with epilepsy. Epilepsy Behavior 2020;104(A):106900.

https://doi.org/10.1016/j.yebeh.2020.106900

11. Šedienè P. Epilepsija sergančiu asmenu psichosocialinè situacija: tarpdalykinès komunikacijos ir kūrybiško bendradarbiavimo prielaidos: mokslinè monografija. LSMU leidybos namai, 2020:176.

12. Patton MQ. Qualitative research \& evaluation methods. SAGE Publications 2014:832.

13. Liamputtong P. Qualitative research methods. Oxford University Press 2019:440.

14. Machalicek W, Lang R, Raulston TJ. Training parents of children with intellectual disabilities: trends, issues, and future directions. Current Developmental Disorders Reports 2015;2(2):110-118. https://doi.org/10.1007/s40474-015-0048-4

15. Sälke-Kellerman RA. Epilepsie bei Schulkindern. Schriften über Epilepsie. Hamburg: Stiftung Michael 2009;4.

16. Schöndienst M. Psychotherapeutische und verhaltenspsychologische Ansätze in der Epilepsiebehandlung. In: Wolf P. (Hrsg). Praxisbuch Epilepsien. Stuttgart: Kohlhammer 2003:240-247.

17. Huus K, Olsson LM, Andersson EE, et al. Perceived needs among parents of children with a mild intellectual disability in Sweden. SJDR 2017;19(4):307-317. https://doi.org/10.1080/15017419.2016.1167773

18. Hedderly T, Baird G, McConachie H. Parental reaction to disability. Current Paediatrics 2003;13(1):30-35. https://doi.org/10.1054/cupe.2003.0406

19. Novelskaitė A, Pučètaitè R. Public trust in civil service organizations and civil servants in Lithuania: findings from a representative survey. Public Policy Administration 2018;17(1):126-140. https://doi.org/10.5755/j01.ppaa.17.1.20613

20. Bali A, et al. Integrated care for childhood epilepsy: ongoing challenges and lessons for other long-term conditions. Archives Disease Childhood 2016;101(11):1057-1062.

https://doi.org/10.1136/archdischild-2015-309794

\section{SHAPING AN INTEGRATED CARE MODEL FOR CHILDREN WITH EPILEPSY AND DEVELOPMENTAL DISORDERS AND THEIR FAMILIES}

P. Šedienè, R. Jurkuvienè, R. Butkevičienė, L. Danusevičienè, I. Gajdosikienė

Keywords: children with epilepsy and developmental disorders, family needs, child and family centred care, integrated care. Summary

Epilepsy is a multietiological neurological disease; one third of children with epilepsy have developmental disorders. Children with the condition need long-term care usually provided by parents. Often the medical aspects of epilepsy dominate, however, studies show that stigmatisation and negative coping strategies used by the children and their families sometimes have even more severe consequences for a child's life than the disease itself, making the whole situation a difficult burden for parents. To improve the quality of life of these families, recent research pays much attention to the needs of the patient and his family. A qualitative study was conducted in Lithuania to find out about these needs and to shape a model of help by interviewing 12 mothers raising such children. The study found that for parents, besides fulfilling the needs related to child's health situation and stabilisation of seizures, fulfilment of needs related to child's education and socialisation are important, as well as psycho-emotional and social support for the family. Parents often feel left alone with their problems despite the services provided to them by the various systems; moreover, such families tend to get isolated instead of integrated into society. If support and services for families raising children with epilepsy and developmental disabilities were provided on the basis of a child- and family-oriented model, linking health, education and social systems (integrating them both horizontally and vertically), the situation of these families and children would improve. Specialized Center for epilepsy psychosocial counselling is suggested as one of the main elements of integrated care for such families.

Correspondence to: ruta.butkeviciene@1smuni.lt

Gauta 2020-08-31 